\title{
Hydrologické a hydrogeologické poměry povodí Lišanského potoka u Rakovníka
}

\section{JAN KAŠPÁREK}

Klíčová slova: podzemní voda - povrchová voda - zaniklý rybník - důl

\section{SOUHRN}

Tématem př́spěvku je rozbor hydrologických a hydrogeologických poměrů v malé části dolního povodí Lišanského potoka u Rakovníka, kde od 15. století byl prírozený stav ovlivněn lidskou činností. Na potoce byl po několik století rybník a v oblasti probíhala intenzivní hlubinná těžba uhlí. V článku jsou popsána a vyhodnocena měření úrovně hladiny podzemní vody na hydrogeologických vrtech a měření průtoků na Lišanském potoce. Výsledkem je vymezení úseku Lišanského potoka, kde je dotována zásoba podzemní vody povrchovou vodou z vodního toku.

\section{ÚVOD}

V letech 2009-2011 byl ve Výzkumném ústavu vodohospodářském T. G. Masaryka řešen úkol Možnosti zmírnění důsledků klimatické změny zlepšením akumulačních schopností v povodí Rakovnického potoka [1]. V rámci tohoto úkolu byla sledována hladina podzemní vody v rozsáhlé síti vrtů a studní a měřeny průtoky významnějších tokư v povodí Rakovnického potoka po profil vodoměrné stanice ČHMÚ v Rakovníku. Jedním z výsledků vyhodnocení těchto měření bylo zjištění a ověření úseků, kde je zásoba podzemní vody dotována z úseků Kolešovického a Rakovnického potoka nad Rakovníkem a z Lišanského potoka v oblasti nad bývalým Velkým rybníkem u Rakovníka. Rakovnický potok nad Rakovníkem a dolní část Kolešovického potoka protékají územím, kde je dlouhodobý pokles úrovně hladiny podzemní vody pod úrovní hladiny toků daný odběry vody (pro vodárenské účely a čerpání vody z dolu). Lišanský potok protéká územím, kde ovlivnění odběry není významné.

Na základě měření úrovně hladiny podzemní vody v soustavě vrtů a studní byla sestrojena mapa isolinií výšky hladiny podzemní vody v Rakovnické pánvi, ve studii viz [1] byl zpracován hydraulický model proudění podzemní vody. Na obr. 1 je výřez z mapy isolinií výšky podzemní vody z okolí Rakovníka.

Obsahem príspěvku jsou zjištění a upřesnění hydrologických a hydrogeologických poměrů na dolním toku Lišanského potoka, v úseku od usedlosti Na cikánce po hráz bývalého Velkého rybníka.

\section{GEOLOGICKÝ POPIS}

Zájmová oblast se nachází severně od rozhraní proterozoika a karbonu. Proterozoikum je tvořeno břidlicemi, které jsou na povrchu patrné u bývalé hráze Velkého rybníka nad Hamrem, u silnice Rakovník-Nové Strašecí a u hráze Žákova rybníka a které na povrch vystupují také u Rakovnického potoka v místě mostu železnice. Břidlice jsou pro podzemní vodu málo propustné a tvoří u Rakovníka bariéru, která vzdouvá hladinu podzemní vody.
Pískovce karbonu na sever od rozhraní překrývají hlouběji uložené proterozoické břidlice. V oblasti dnešní Šamotky byla nalezena a těžena uhelná sloj (svrchní radnické vrstvy).

Mocnost karbonských vrstev a poloha podložních břidlic je v oblasti velmi rozdílná. Písky a jíly karbonského moře se postupně usazovaly na členitém podkladu a následně byly zpevněné sedimenty posouvány tektonickými pohyby. Značná členitost je patrná na geologických profilech vrtů, které jsou i v blízkých vrtech poměrně odlišné. Tektonické poruchy vzhledem k př́tomnosti jílů jsou zde pro podzemní vodu málo propustné. Nivu Lišanského potoka tvoří kvarterní hlíny, písky, jílovité písky a zahliněné štěrkopísky.

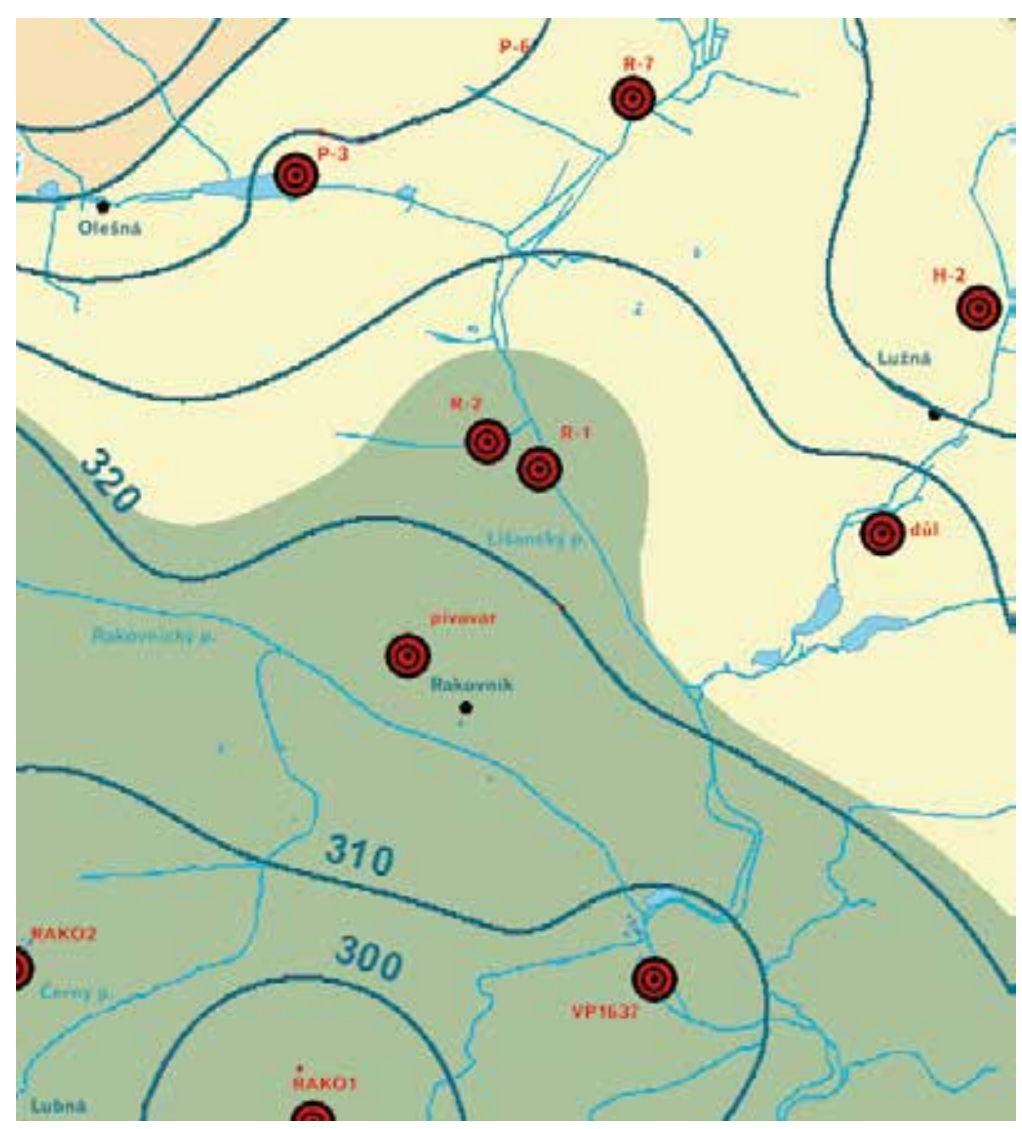

Obr. 1. Isolinie výšky hladin podzemní vody okolí Rakovníka Fig. 1. Isolinias of groundwater level near the Rakovník 
Severní okraj oblasti je vymezen predpokládanou tektonickou poruchou probíhající přibližně u usedlosti Na Kordech, na východní straně tektonikou shodnou se směrem údolí Lišanského potoka. Západním a jihozápadním směrem je oblast otevřená, kolektor podzemní vody pokračuje pod Rakovník.

\section{HISTORICKÉ SOUVISLOSTI}

Pod soutokem Lišanského (dřive Červeného) potoka s Čistým potokem byl od roku 1482 rybník. Založení hráze bylo výhodně vybráno v místě výchozu břidlice. Dá se předpokládat, že již před založením rybníka zde byl krátký úsek toku s větším sklonem. Výpust’ rybníka a náhon k hamru mohly být vylámány v pevné skále u levého břehu potoka. Pưvodně malý rybník byl dále rozšiřován. Roku 1524 byl rybník rozdělen druhou hrází, větší dolní část v údolí Lišanského potoka si zachovala pưvodní název Velký rybník, horní část na Čistém potoce se jmenovala Kavan. Vodní energie poháněla hamr, později mlýn. Hráz rybníka je do dnešní doby zcela zachována, po její koruně vede silnice Rakovník-Nové Strašecí a Lišanský potok zde protéká ve skále vytesanou výpustí rybníka. Na obr. 2 je zobrazený Velký rybník a Kavan na mapě důlních měr z roku 1860. Důlní míry zanesené západně od rybníků nejsou na černé uhlí, ale jsou na železnou rudu. K významnější těžbě nedošlo.

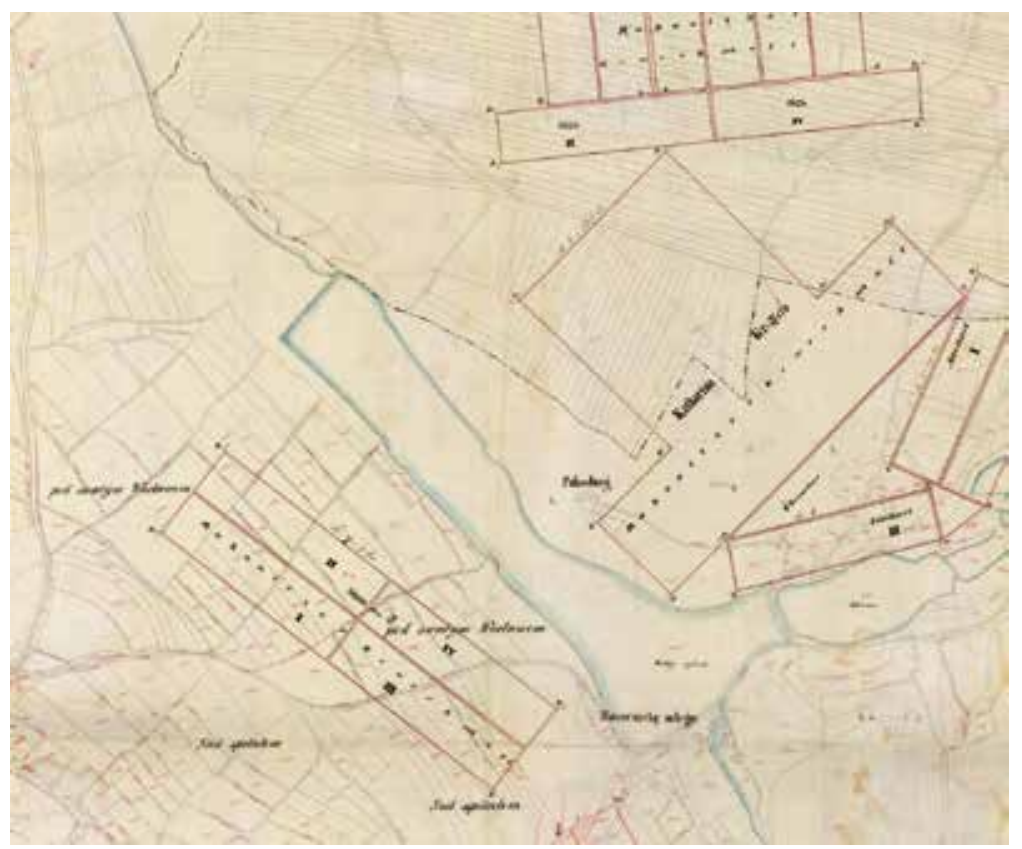

Obr. 2. Velký rybník a Kavan na mapě důlních měr z roku 1860

Fig. 2. The Velký rybník and Kavan on the map of the 1860

Změna přišla v polovině 19. století. Jak byl skalní výchoz pro založení hráze rybníka výhodný, tak po nálezu uhlí, jehož sloj je zde stejně jako podložní břidlice mělko pod povrchem, se stalo jeho umístění problematickým.

$\checkmark$ roce 1847 je započato za Velkým rybníkem hloubení první šachty podnikatele Jana Herolda. Dobývání uhlí se rychle rozrůstalo, na poměrně malém prostoru bylo postupně založeno kolem dvaceti důlních šachet. Těžbu stále komplikovala prosakující voda z rybníků. V roce 1869 Herold odstoupil, podniku se ujali podnikatelé z Brna a založili společnost Moravia. Následujícího roku zrušili a vysušili oba rybníky. Po vypuštění Kavanu bylo pod bývalým blátivým dnem nalezeno uhlí v malé hloubce a byla zde zahájena povrchová těžba odklizem. Také byla prèežena silnice do Rakovníka do dnešní trasy tak, aby nevedla důlním areálem. Z důlních šachet byly významné Mořic, Jan a Kateřina, kde voda byla čerpána parními stroji. V důsledku čerpání dochází k poklesu hladiny podzemní vody, je zaznamenáno vyschnutí studánek a studní ve městě [2]. Podle údajů z důlních map byla podzemní voda čerpána z hloubky v úrovni nejméně $260 \mathrm{~m}$ n. m., tj. přibližně $60 \mathrm{~m}$ pod úrovní terénu u Lišanského potoka $\checkmark$ oblasti nad dolem.

Voda byla také príčinou konce těžby uhlí. Poprvé doly zaplavila katastrofická povodeň v roce 1872, ale voda byla vyčerpána, těžba pokračovala, společnost dosáhla vrcholu rozkvětu v letech 1875 a 1876. Roku 1877 při povodni byly doly opět zatopeny a zatopena byla i nová výkonná čerpadla. V květnu 1882 přišla další povodeň, došlo k zátarasu v propustku bývalé hráze a naplnění zrušeného rybníka. Nadržená voda se provalila do důlního podzemí prolomením nadloží nebo větrací jámou. Stalo se to na pravém břehu Lišanského potoka, nedaleko nad hrází. Při tomto neočekávaném neštěstí zahynuli tř̌i horníci. Z tohoto neštěstí se vyčerpané doly nevzpamatovaly, malá těžba probíhala ještě do roku 1885. $\checkmark$ roce 1886 bylo ukončeno čerpání vody, hladina podzemní vody se zvýšila, ve městě nastaly problémy s podzemní vodou ve sklepech [2]. Př́kladem je Dívčí škola (dnes 2. základní škola Rakovník) na náměstí, která byla postavena v letech 1885-1886.

Z povrchových objektů dolů byla vybudována továrna na keramiku Šamotka, její provoz byl zahájen v roce 1883.

Povrchová dobývka na uhlí v prostoru zrušeného rybníka Kavan byla také zatopena podzemní vodou, vznikl Oprám, ze kterého byla později čerpána voda pro provoz Šamotky. Po roce 1945 byl Oprám zavážen odpadem z Šamotky a jeho velikost se tak zmenšila. Na přelomu dvacátého a jednadvacátého století byla provedena rekultivace Oprámu a změna vodního režimu. Do té doby byl Oprám napájen jen podzemní vodou, nově je průtočný, byl vybudován přívod vody z Čistého potoka a odtok.

\section{POZOROVÁNÍ}

\section{Starší pozorovací objekty}

V oblasti proběhlo několik hydrogeologických průzkumů [3-5], po kterých jsou zde hydrogeologické vrty R1 až R-5, P-5, VS-1 a RK-1. V terénu byla dohledána studánka - pramen Na Cikánce, studna u TJ (TJ Tatran), studna v areálu Šamotky a pramen ve sklepě školy (2. základní škola Rakovník) na náměstí.

\section{Nově zř́zená pozorování}

Pro upřesnění hydrogeologických poměrů byly v rámci úkolu [1] vyhloubeny mělké pozorovací vrty P-1, P-2, P-3. Nadmořské výšky vrtů byly geodeticky zaměřeny.

Vrty R-1, R-2, P-5, VS-1, P-1 a studna u TJ byly sledovány automatickými hladinoměry. Po ověření podobnosti průběhů vrtů R-1, R-2 a VS-1 byly vyřazeny ze sledování vrty R-2 a VS-1 a pozorování ponecháno na vrtu R-1. Vzhledem k velkému ovlivnění čerpáním bylo ukončeno pozorování studny TJ. Vydatnost pramene Na Cikánce a hladina podzemní vody ve vrtech RK-1, P-2, P-3 byly měřeny s měsíční periodou, úroveň hladiny podzemní vody ve studni v Šamotce a pramenu ve sklepě školy byly změřeny jen jednorázově. Přetok vrtu R-4 a dalších vrtů (R-5, R-7) byly ověřeny v terénu. Hladina podzemní vody ve vrtu R-3 a v zajištovacím vrtu v jámě Kateřina byla zjištěna pouze z dostupných informací $[5,6]$.

$\mathrm{Na}$ Lišanském potoce $v$ profilu Na Cikánce byla zřizena v roce 2009 vodoměrná stanice tvořená měrným přelivem se záznamem hladiny automatickým hladinoměrem. Poloha vodoměrné stanice a sklon Lišanského potoky byly geodeticky zaměřeny.

Na redukované sestavě pozorovacích objektů R-1, P-1, P-5 a vodoměrné stanici na Lišanském potoce pozorování pokračuje. 
Mapa sledovaných objektů podzemní vody, polohy zaniklého Velkého rybníka a plochy vyrubané doly Moravia je na obr. 3.

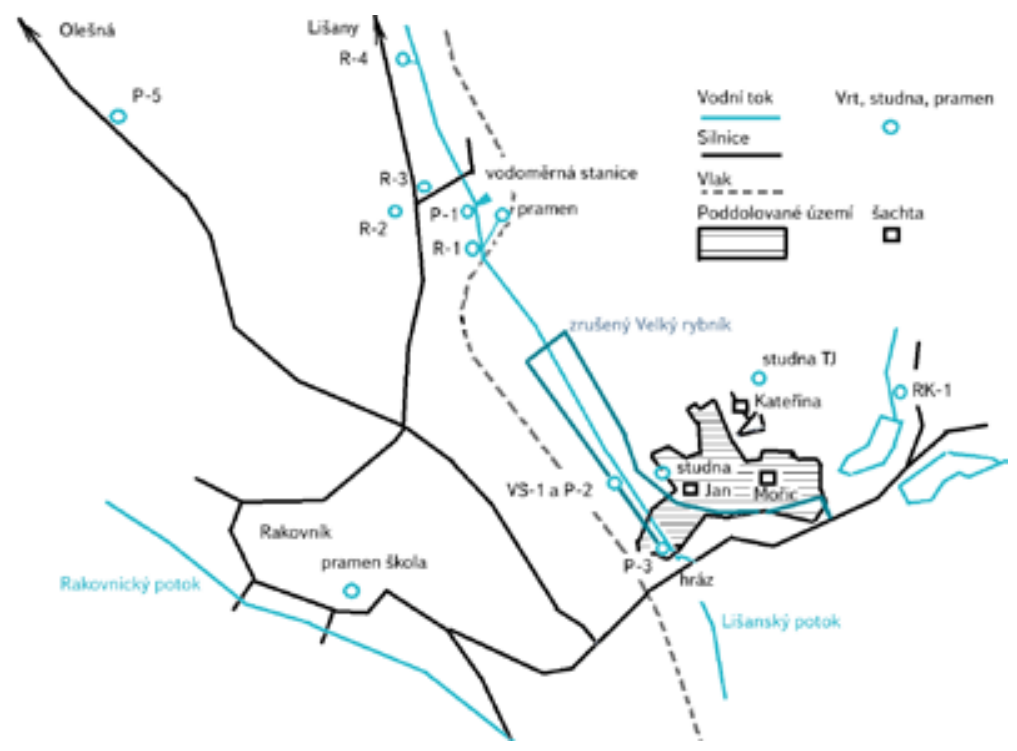

Obr. 3. Schématická mapa oblasti

Fig. 3. Schematic map of the area

\section{Rozbor výsledků pozorování}

Na severní straně zájmové oblasti je patrný pokles úrovně hladiny podzemní vody. Výše proti proudu Lišanského potoka je úroveň hladiny podzemní vody vyšší než běžná hladina potoka, hluboké vrty (R-4 a dále výše R-5 a R-7) mají trvale přetok vody a u usedlosti Na Kordech je vrt R-3 s hladinou 1,5 m pod terénem. Na předpokládané tektonické poruše hladina podzemní vody výrazně klesá, ve vrtech R-1 a R-2 je hladina podzemní vody o 2,7 m niže než ve vrtu R-3, při vzdálenosti mezi R-2 od R-3 $140 \mathrm{~m}$. Průměrná úroveň hladiny vrtu R-1 je 320,77 m n. m. (2010-2016). Pramen Na Cikánce je napájen z kolektoru nad tektonickou poruchou [3], vydatnost se pohybuje od 0,06 I/s do 0,25 I/s (2011-2015).

$\checkmark$ oblasti s nižší hladinou podzemní vody je ve vrtech R-1, R-2 a VS-1 hladina podzemní vody na přibližně stejné úrovni. Ve vrtech R-1 a R-2 je časový průběh kolísání hladiny shodný, ve vrtu VS-1 podobný, s menším rozpětím změny průběhu. Hydraulická souvislost vrtu R-1 a vrtu VS-1 byla ověřena při čerpání vrtu R-1 viz [3]. Hladina podzemní vody blízká hodnotě ve výše uvedených vrtech byla zjištěna ve studni v areálu Šamotky a dále zastižena zajištovacím vrtem při likvidaci jámy Kateřina v roce 2003 [6].

Při čerpací zkoušce vrtu VS-1 v roce 1970 byl zaznamenán pokles hladiny Oprámu, ve zprávě viz [4] je pravděpodobnost souvislosti s čerpáním vrtu sice zpochybněna, ale ne zcela vyloučena.

V objektech situovaných dále na východ (studna TJ a vrt RK-1) je hladina podzemní vody výrazně výše a časový chod hladiny je zde jiný.

Pramen ve sklepě školy na náměstí je položen níže na úrovni 313,7 m n. m.

Západně ve vzdálenosti $1,6 \mathrm{~km}$ od vodoměrné stanice na Lišanském potoce byla měřena hladina na vrtu P-5, která je na úrovni mírně vyšší než ve vrtu R-1, s pozvolným chodem změn výšky hladiny. $V$ prostoru mezi sledovanou oblastí a vrtem P-5 se nepodařilo dohledat žádný hydrogeologický vrt, souvislost se stejným kolektorem Ize tedy jen předpokládat.
Pod hrází zaniklého rybníka je úroveň hladiny vody $v$ Lišanském potoce 315,5 m n. m., tj. výrazně pod úrovní hladiny podzemní vody nad hrází. V oblasti toku pod hrází nejsou patrné vývěry podzemní vody a podélná měření průtoku v potoce neprokázala prírůstek průtoku. Hráz rybníka, resp. výchoz podložních břidlic, tedy ohraničuje kolektor v karbonských pískovcích.

Údaje o nadmořských výškách hladiny podzemní a povrchové vody jsou souhrnně uvedeny v tabulce 1. Podélný profil Lišanského potoka a výška hladiny podzemní vody jsou zobrazeny na obr. 4.

Tabulka 1. Nadmořské výšky terénu u pozorovacích objektů a hladiny podzemní a povrchové vody

Table 1. Terrain elevations at observation objects and groundwater and surface water levels

\begin{tabular}{lllll} 
Objekt & Hloubka & Terén & Hladina & Poznámka \\
\hline vrt R-4 & 100 & 326 & 326,3 & přetok \\
\hline vrt R-3 & 93,6 & 325 & 323,4 & \\
\hline pramen Na Cikánce & 1 & 324 & 324 & \\
\hline vrt R-2 & 100,8 & 329 & 320,7 & \\
\hline vrt R-1 & 62,3 & 324 & 320,77 & \\
\hline vrt VS-1 & 72,5 & 320,6 & 320,66 & \\
\hline studna Šamotka & 16,9 & 336 & 321,2 & k 31. 8.2011 \\
\hline jáma Kateřina & 93 & 368 & 317 & zajištění 2003 \\
\hline studna TJ & $>80$ & 366,9 & 331,83 & \\
\hline vrt RK-1 & 38,8 & 331,9 & 329,5 & \\
\hline vrt P-5 & 80 & 376 & 322,5 & \\
\hline pramen škola & & 317 & 313,7 &
\end{tabular}

Poznámka:

Vrt VS-1 je v 19 m neprüchozí, hydraulické propojení se zvodní bylo overéeno čerpací zkouškou. Studna TJ podle ústniho sděleni a zprávy k zajištění jámy Kateřina [6] je údajně duilni dílo. Vzhledem k poloze, hloubce a stavebnimu provedení je to pravděpodobné. Hladina je zde podstatně výše než ve vrtech R-2, R-1 a VS-1. Vydatnost tohoto zdroje je malá. Pokud je studna u TJ bývalé dưlní dilo, není podle těchto poznatkư hydraulicky propojené s dolem Moravia. Dưlní mapy dolu Moravia do této oblasti nezasahují.

Při podélných měřeních průtoku na Lišanském potoce byl opakovaně zjištěn úbytek v úseku od usedlosti Na Cikánce ke stupni v korytě u vrtu vS-1 velikosti do $10 \mathrm{l} / \mathrm{s}$ a dále mírná dotace $v$ úseku od VS-1 k hrázi zaniklého rybníka. Tyto výsledky měření průtoků odpovídají relaci výšky toku k výšce hladině podzemní vody. $V$ dnešní době bude proti období 2009-2011 dotace Lišanského potoka v úseku od vrtu VS-1 k hrázi zaniklého rybníka menší, vznikl zde zátaras (bobří hráz) a tok je na delším úseku oboustranně rozlitý a protéká nivou, hladina toku je výše.

Úroveň hladiny ve velkém rybníce podle odečtu ze starých map a podle zaměření výšky náhonu k Hamerskému mlýny byla kolem 321 m n. m.

Pro sledování hladiny podzemní vody ve svrchní zvodni byly vyhloubeny mělké vrty P 1-3. Sondy P-1 a P-2 vrtány do hloubky 3 m, sonda P-3 je hluboká $5 \mathrm{~m}$. Sondy zastihly jíly, písčité jíly a písky.

Vrt P-1 je u vodoměrné stanice na Lišanském potoce, na pravém břehu, ve vzdálenosti $11 \mathrm{~m}$ od toku. Hladina je měřena automatickým hladinoměrem. 


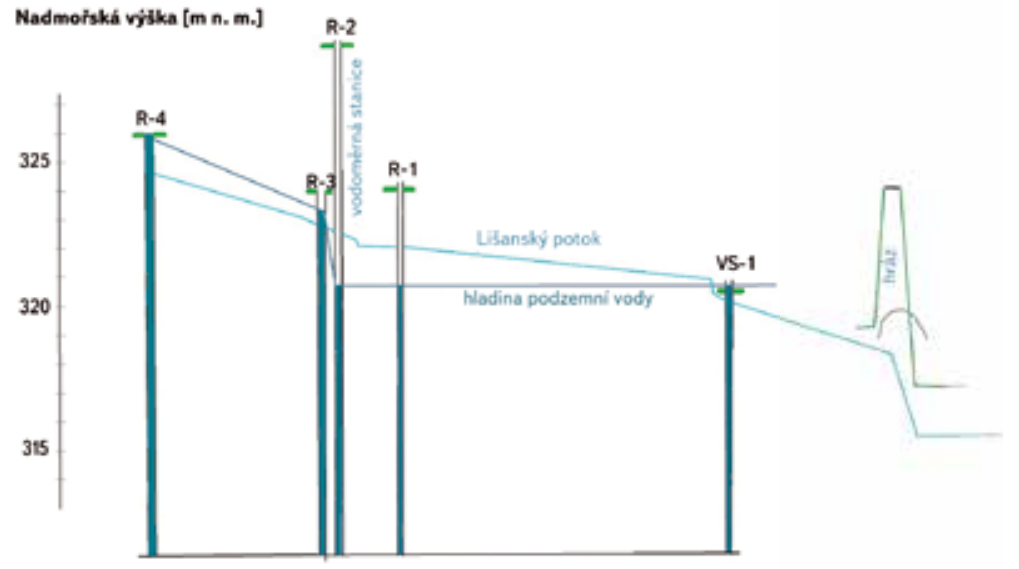

Obr. 4. Podélný profil úseku Lišanského potoka od vrtu R-4 po hráz zrušeného rybníka Fig. 4. Longitudinal profile of the Lišanský brook from the borehole R-4 to the dam of the canceled pond

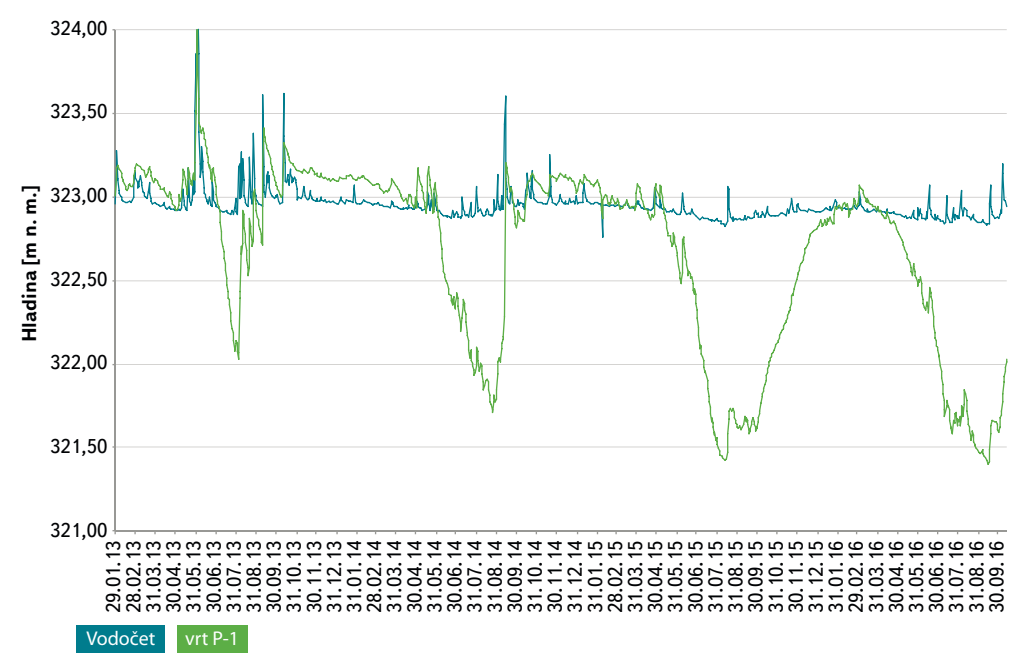

Obr. 5. Hladina v sondě P-1 a hladina v potoce na měrném profilu

Fig. 5. P-1 probe level and creep level on the profile

Průběh úrovně hladiny ve vrtu P-1 a hladiny vody v Lišanském potoce (stav vodočtu vodoměrné stanice) je znázorněn na obr. 5. V letních měsících zde dochází k poklesu hladiny svrchní zvodně pod úroveň hladiny toku. Je zde výrazné prodloužení období poklesu hladiny podzemní vody s nástupem současného sucha.

Další mělké sondy byly vyhloubeny níže po proudu potoka. Vrt P-2 v blízkosti hlubokého vrtu VS-1 a nad hrází zaniklého rybníka v poddolovaném území je umístěna sonda P-3. U sond P-2 a P-3 je hladina nad běžnou úrovní hladiny toku. U sondy P3 se zvětšující se hloubkou vrtání úroveň hladina vody v sondě stoupala, po dokončení sondy na hloubce $5 \mathrm{~m}$ se ustálil mírný přetok 0,01 l/s.

Z Lišanského potoka, vrtu R-1, vrtu VS-1 a sondy P-3 byly odebrány vzorky vody na chemický rozbor, výsledky jsou v tabulce 2. Z výsledků rozboru je patrný mírně vyšší obsah dusičnanů v povrchové vodě a vyšší obsah síranů a vyšší vodivost vzorků z vrtu VS-1 a P-3, které souvisí s blízkostí zatopeného dolu.

\section{ZÁVĚR}

Sledovaná oblast je součástí (severovýchodním okrajem) rozsáhlého kolektoru podzemních vod rakovnické permkarbonské pánve. Západním a jihozápadním směrem kolektor pokračuje pod město, kde jsou odběrové vrty rakovnického
Tabulka 2. Chemický rozbor podzemní a povrchové vody

Table 2. Chemical analysis of underground and surface water

\begin{tabular}{llllll} 
Ukazatel & Jednotka & R-1 & VS-1 & P-3 & Lišanský \\
\hline CHSK-Mn & $\mathrm{mg} / \mathrm{l}$ & 2,78 & 1,21 & 5,06 & 5,38 \\
\hline chloridy & $\mathrm{mg} / \mathrm{l}$ & 38,6 & 28,4 & 28,5 & 31,3 \\
\hline sírany & $\mathrm{mg} / \mathrm{l}$ & 52 & 214 & 214 & 84 \\
\hline amonné ionty & $\mathrm{mg} / \mathrm{l}$ & 0,34 & 0,35 & 3,8 & 0,47 \\
\hline dusičnany & $\mathrm{mg} / \mathrm{l}$ & 1,72 & $<1$ & $<1$ & 26,8 \\
\hline $\mathrm{P}_{\text {celk }}$ & $\mathrm{mg} / \mathrm{l}$ & 0,0504 & 0,034 & 0,781 & 0,0923 \\
\hline pH & & 6,87 & 5,8 & 6,2 & 7,4 \\
\hline vodivost & $\mathrm{mikroS/cm}$ & 404 & 798 & 840 & 591 \\
\hline teplota & ${ }^{\circ} \mathrm{C}$ & 9,5 & 9,4 & 12,2 &
\end{tabular}

pivovaru, prameny ve sklepech budov na náměstí, a dále za Rakovnický potok, kde je hladina podzemní vody trvale snížena čerpáním dolu Rako a odběrem pro vodárenské účely. Sklon hladiny podzemní vody od zájmové oblasti je západním a jihozápadním směrem k Rakovníku.

$\checkmark$ úseku Lišanského potoka přibližně od cesty $k$ pískovně nad vodoměrnou stanicí po stabilizační stupeň u vrtu VS-1 (obr. 3) je podzemní voda dotována z toku. Tento úsek přináší riziko zranitelnosti zásoby podzemní vody. Lišanský potok má vodu poměrně kvalitní a průtok trvale mírně nadlepšený vypouštěním odpadních vod pivovarem v Krušovicích, ale v případně havarijního znečištění vody v potoce nelze vyloučit nebezpečí zhoršení jakosti podzemní vody.

Rozvaha, zda současný stav je optimální, nebo vhodnou úpravou toku a okolí toku dotaci podzemní vody z povrchové zvětšit nebo zmenšit, by byla tématem pro rozsáhlejší studii, s ohledem na odběry podzemní vody z kolektoru, prameny ve sklepech ve městě a jakost povrchové a podzemní vody.

Vyrubané prostory dolu Moravia jsou pod úrovní hladiny podzemní vody (odhadovaný objem $250000 \mathrm{~m}^{3}$ [1]). Bilančně se na chodu podzemní a povrchové vody nepodílejí. Vrt VS-1 v blízkosti zatopeného dolu má pro tuto oblast nezvykle velkou specifickou vydatnost, a to $8 \mathrm{l} / \mathrm{s} / \mathrm{m}$ [4], průměrná vydatnost artéských vrtů je $v$ této oblasti $0,15 \mathrm{l} / \mathrm{s} / \mathrm{m}$. Je tu možnost opravou tohoto vrtu nebo vyhloubením nového v oblasti stařin dolu Moravia pořídit vydatný zdroj vody ale s vyšším obsahem síranů. Dále je možnost volného přetoku podzemní vody z vrtu do potoka (dřive byl vrt VS-1 s přetokem pod úrovní terénu, dnes je na vrtu novější pažnice a přetok už není, hladina je nad terénem).

Poznatky z tohoto průzkumu se týkají problému prípadného obnovení Velkého rybníka. Napuštění rybníka, i v menším rozsahu, by vedlo k podstatnému zvýšení dotace podzemní vody. Výsledkem by bylo zhoršení jakosti podzemní vody a zvýšení vydatnosti pramenů ve sklepech ve městě. Př́padné těsnění dna rybníka by muselo být velmi pečlivé, s ohledem na poddolování oblasti.

Kromě těchto praktických závěrů je tato malá oblast zajímavou ukázkou vlivu lidské činnosti na povrchovou a podzemní vodu. Nejprve pro vhodné podmínky souvisejícís výchozem pevného podloží byl založen rybník. Po založení rybníka zajisté došlo k zvýšení vydatnosti pramenů ve městě. Později, opět $\checkmark$ prímé souvislosti s geologií podloží, rybník ustoupil uhelným dolům a hladina podzemní vody je na krátké období výrazně snížena čerpáním. A po ukončení těžby, na kterém se kromě vyčerpání sloje podílely i povodně Lišanského potoka, se poměry vrací do stavu blízkého původnímu. 


\section{Literatura}

[1] HORAČCK, S. a KAŠPÁREK, L. Možnosti zmírněni současných důsledků klimatické změny zlepšením akumulačni schopnosti v povodi Rakovnického potoka. Praha: Výzkumný ústav vodohospodářský T. G. Masaryka, v. v. i., 2011.

[2] HOVORKA, F. Rakovnické paměti 19.století. Rakovník/Praha: Státní okresní archiv Rakovník/Státní oblastní archiv v Praze, 2010

[3] CHVAL, D., ČAPEK, A., KOKOŠOVÁ, L. a KŘIVKA, V. Rakovník - zhodnocení hydrogeologických průzkumných vrtů v povodí Lišanského potoka. Praha: Vodní zdroje, 1984.

[4] HAVLA, H. Zpráva o hydrogeologickém průzkumu pro mlékárnu Rakovník. Praha: Potravinoprojekt, 1970. [5] ČERNÝ, I. Rakovník RKZ. Praha: Vodní zdroje, 1978

[6] ŠARBOCH, P. Závěrečná zpráva likvidace starého důlního díla jámy Kateřina v Lužnéu Rakovníka. Kladno: Služby dolů, a. S., 2003.

\section{Autor}

\section{Jan Kašpárek}

凶jan.kasparek@vuv.cz

Výzkumný ústav vodohospodářský T. G. Masaryka, v. v. i.

\section{HYDROLOGICAL AND HYDROGEOLOGICAL CONDITIONS OF THE LIŠANSKÝ STREAM NEAR RAKOVNÍK}

\section{KASPAREK, J.}

TGM Water Research Institute, p. r. i.

Keywords: groundwater - surface water - defunct pond - mine

The article describes hydrological and hydrogeological conditions in a small part of the Lišanský stream catchment near Rakovník. Natural conditions of this area have been influenced by human activity from the $15^{\text {th }}$ century. There used to be a pond at the creek for several centuries and intensive deep coal mining took place in this area. The article evaluates measurements of groundwater level in hydrogeological boreholes and flow measurements on the Lišanský stream. The aim of the analysis is to identify a section of the Lišanský stream, where the surface water percolates into the groundwater.

Příspěvek prošel lektorským řízením.

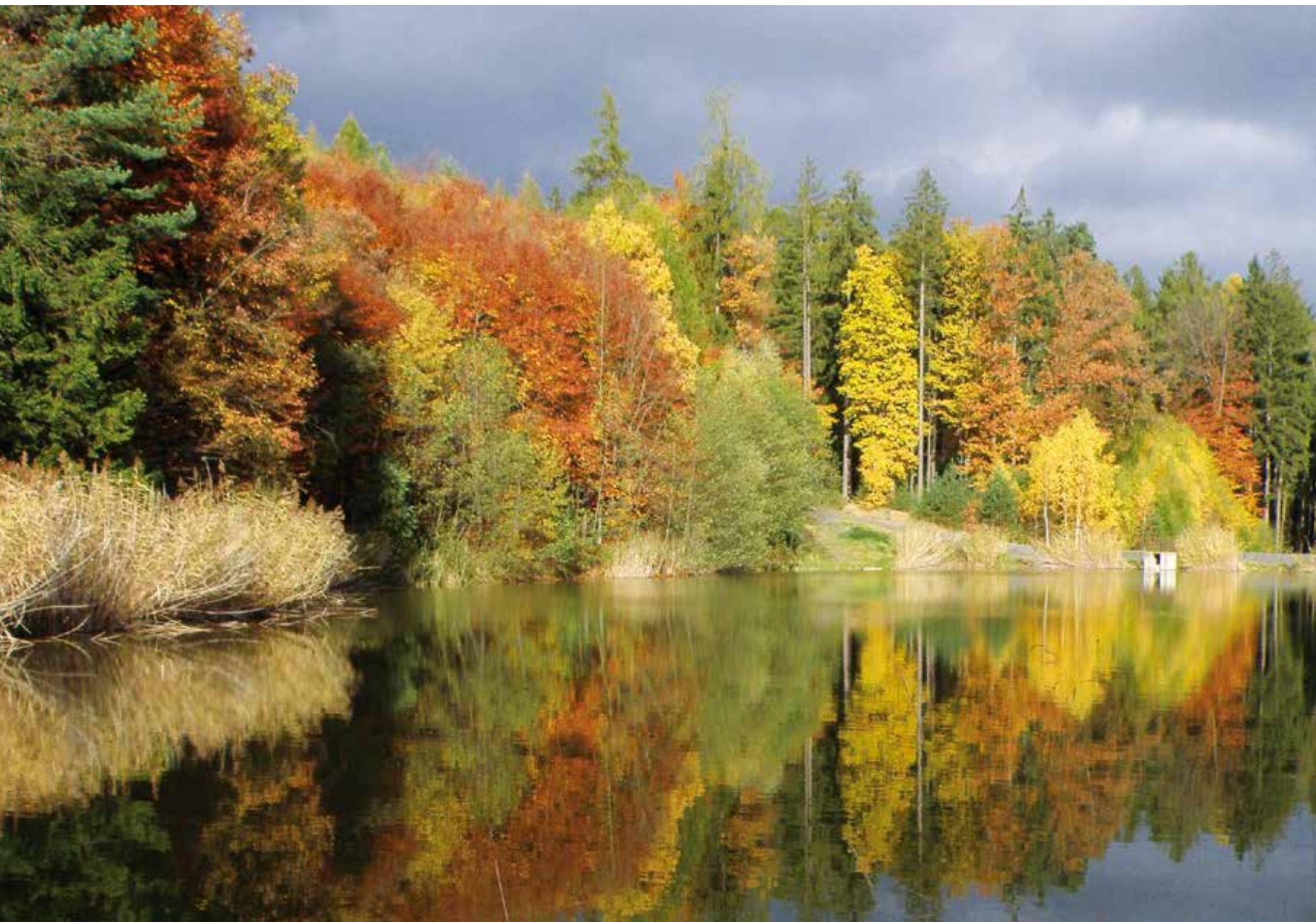

